\title{
Downward trophic shift during breeding migration in the shorebird Calidris mauri (western sandpiper)
}

\author{
Peter G. Beninger ${ }^{1, *}$, Robert W. Elner ${ }^{2}$, Michèle Morançais ${ }^{1}{ }^{1}$ Priscilla Decottignies ${ }^{1}$ \\ ${ }^{1}$ Laboratoire de Biologie Marine, Faculté des Sciences, Université de Nantes, 44240 Nantes Cédex, France \\ ${ }^{2}$ Canadian Wildlife Service, Pacific Wildlife Reseach Centre, Environment Canada, RR 1, 5421 Robertson Road, Delta, \\ V4K 3N2 British Columbia, Canada
}

\begin{abstract}
The recent demonstration of mudflat surficial biofilm feeding by western sandpiper Calidris mauri has provided new insight into the feeding ecology of shorebirds. We assessed feeding modes over the migratory cycle, and specifically whether a downward shift in trophic position occurred during the 2004 northward migration from their overwintering areas to the Arctic breeding grounds. We used stable isotope composition and calculated trophic positions of adult western sandpiper at their northward migratory stopover on Roberts Bank, British Columbia, Canada, in 3 animal compartments with increasing turnover times (stomach contents, liver, and muscle). This allowed the retrospective determination of their major diet source types over time frames encompassing the geographical ranges of their previous migratory stopovers and arrival on the Roberts Bank stopover. Detailed taxonomic and photopigment determinations were also performed on stomach contents and surficial biofilm. The Roberts Bank biofilm showed high taxonomic homogeneity among sampling sites, suggesting a qualitatively consistent food source during western sandpiper stopover. A statistically significant downward shift in mean trophic position (TP) occurred between previous migratory stopovers $(\mathrm{TP}=3.0 \pm 0.5$, mean $\pm \mathrm{SD})$ and arrival on the Roberts Bank stopover, where the maximum probability densities showed $>70 \%$ dietary contribution of benthic diatoms, with a TP $=2.3 \pm 0.4$, close to the diet of the suspension-feeding bivalves Tapes philippinarum and Mya sp. (TP = 2). Advantages of biofilm over macrofaunal feeding during migration may include decreased handling and search time, as well as greater availability and digestibility of the high-energy carbohydrates needed for flight.
\end{abstract}

KEY WORDS: Feeding - Migratory stopover - Mudflat biofilm - Microphytobenthos - Intertidal ecosystems $\cdot$ Dietary changes

Resale or republication not permitted without written consent of the publisher

\section{INTRODUCTION}

Through their long-range migrations and dependance upon the condition of the sea-land interface, shorebirds are important indicators of environmental status (Piersma \& Lindström 2004, Huettmann \& Czech 2006). Migratory shorebirds are important consumers of coastal marine production, especially on intertidal mudflats where their densities may be considerable (Butler et al. 1987, Mawhinney et al. 1993). Habitat is inextricably linked to food supply of migratory birds, and elucidation of stopover spring diets is a high research priority. Migratory stopover habitats, (rest and 're-fuelling' sites over a bird's migratory route) have been identified as one of the least studied aspects of avian migration, despite the importance of pre-nesting activities for reproductive success (see review by Arzel et al. 2006).

Western sandpipers Calidris mauri are long-distance migratory shorebirds that use large coastal stopover sites during northward migration from their wintering range, between California and Peru, to Arctic breeding grounds in western Alaska and eastern Siberia (Wilson 1994, Warnock \& Bishop 1998). The main food source at their Roberts Bank (British Columbia, Canada) migratory stopover is biofilm produced on 
intertidal mudflats (Elner et al. 2005, Kuwae et al. 2008), which is, ipso facto, restricted to the intertidal, soft-bottom habitat type. Many migratory shorebirds typically feed on benthic macroinvertebrates (e.g. Eldridge 1992, Jing et al. 2007), so it is uncertain whether western sandpipers, which overwinter in South America and have several migratory stopovers (Fig 1), utilize biofilm as their main food source throughout their range. Some dietary shift could occur prior to or during migration, as in other migratory shore and water birds. However, in all known examples, the dietary shift has been upwards, i.e. from an herbivorous consumer level to a more energy-rich herbivorous level (e.g. granivorous), or to an omnivorous or carnivorous level (Tsipoura \& Burger 1999, Kvist \& Lindstrom 2003, Arzel et al. 2006). Since microphytobenthos is already a low trophic level, it is appropriate to investigate any eventual diet shift in migrating western sandpipers.

The stable isotope technique can be used to detect migration related diet changes (Rubenstein \& Hobson 2004), by determination of isotopic signatures of a single tissue type to characterize diet in animals from each migratory habitat (e.g. Arthur et al. 2008, Witte- veen et al. 2009). Similarly, a single tissue type, or physiological compartment such as blood, may be used to determine arrival times at migratory habitats (Oppel \& Powell 2009). Alternatively, different tissue types, or physiological compartments (including stomach contents), characterized by different turnover times, should allow the back-calculation of diets along a migration route (e.g. Dalerum \& Angerbjörn 2005, Podlesak et al. 2005).

The use of isotopic techniques has been hampered in diet studies of migratory species, because the exact Southern hemisphere habitats for given individual birds encountered at Northern hemisphere stopovers are not known, rendering conjectural any information concerning trophic sources and exploitation. The discovery of the microphytobenthic feeding mode of western sandpiper introduces the possibility that they can exploit food sources over both the primary and higher trophic levels. If so, then differences in source exploitation could be much larger than differences in isotopic signatures of comparable sources along the migration route (Kelly 2000, Winemiller et al. 2007). The use of food sources at a given point along the

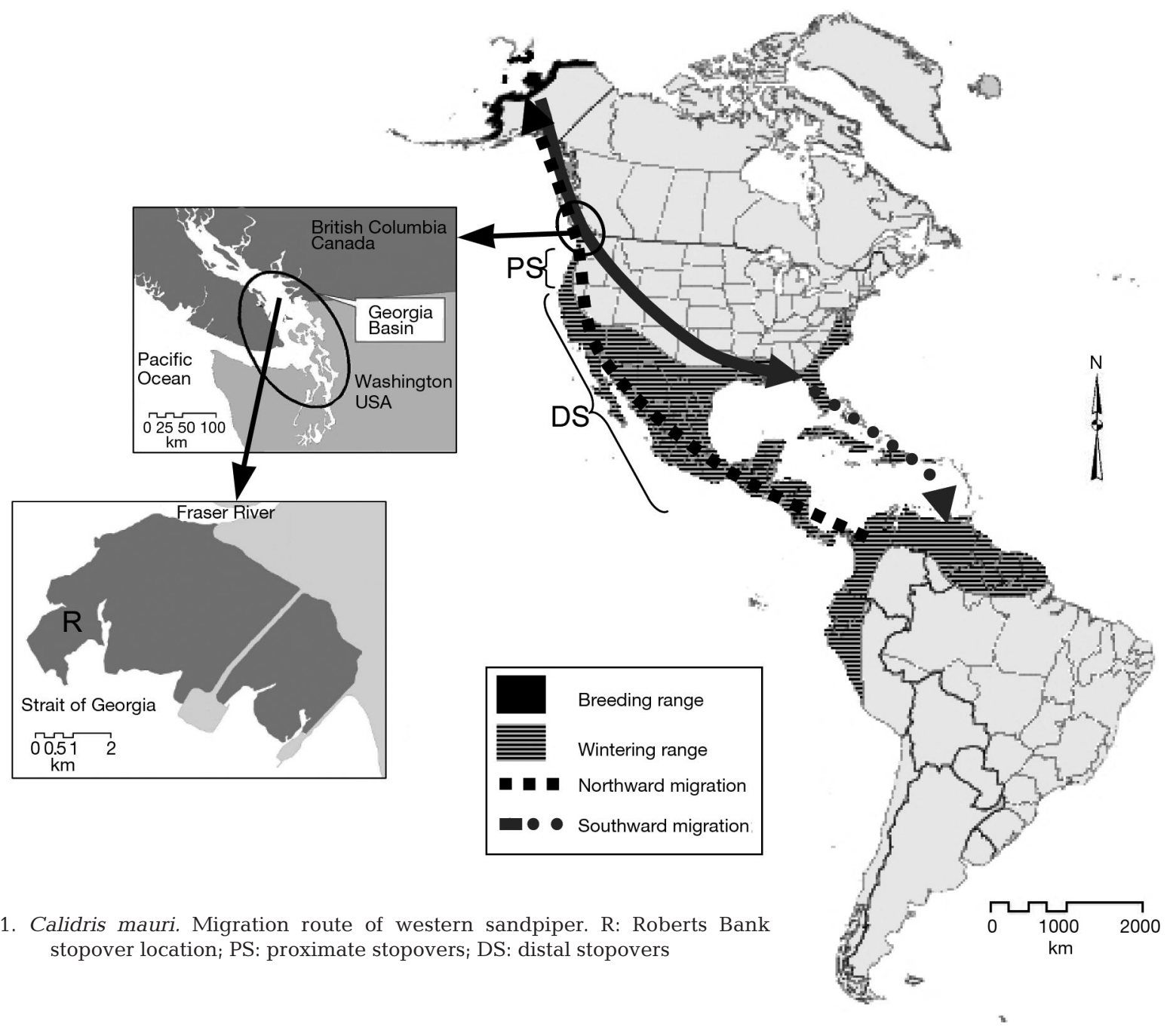


migration route could therefore be used as a proxy for dietary sources throughout the route.

In the present study, we examine the isotopic values of different physiological compartments of western sandpiper sampled at a single migratory habitat (Roberts Bank stopover), in order to reveal eventual migration related dietary changes, by using the tissuespecific turnover times of these isotopes (Hobson \& Clark 1992, Evans-Ogden et al. 2004), and proxy sources at the sampling site.

\section{MATERIALS AND METHODS}

Sampling. A total of 18 western sandpipers were sampled using a shotgun at the Roberts Bank stopover (Fig. $1,49^{\circ} 05^{\prime} \mathrm{N}, 123^{\circ} 12^{\prime} \mathrm{W}$ ), under permit number 5904-0338 issued by Environment Canada, on 22, 25 and 30 April 2004 (see Table 1 for sex and maturity status of individual birds). The birds were feeding at the time of sampling. Of these, 6 birds from the 22 and 25 April samples were used for stable isotope analyses (SIA); birds from April 30 were not used for SIA, since these could have been present on the sampling site for a period long enough to allow the near-complete renewal of liver isotopic composition (almost all birds have left the stopover site by this date). Three birds were used for stomach content observations, and the stomach contents of 9 birds originally used in Kuwae et al. (2008) for cursory pigment analysis were subjected to detailed high performance liquid chromatography (HPLC) in order to identify as completely as possible the photopigments and their degradation products. This data allowed more refined taxonomic resolution of recently ingested photoautotrophs.

A total of 24 sediment cores $\left(\sim 10 \mathrm{~cm}\right.$ depth, $11 \mathrm{~cm}^{2}$ surface area), covered with biofilm, water, and associated macro- and meiofauna, were frozen in situ by addition of liquid nitrogen (Méléder et al. 2005) at low tide on 23, 26 and 30 April 2004. All cores were obtained from muddy sediment within $100 \mathrm{~m}$ of the high-water mark. These sediment cores were processed either for microscopic observations $(n=6)$ or for pigment analyses $(\mathrm{n}=18)$.

Potential food sources for western sandpiper (Wilson 1994) at the stopover site were sampled for SIA at low tide on 23, 25 and 30 April 2004. These samples comprised benthic invertebrate macrofauna, dominated by the bivalves Mya sp., Tapes philippinarum (the only Tapes species present on the Pacific Coast) and Macoma sp., as well as the polychaete Hediste sp., benthic nematodes and copepods, benthic diatoms, and suspended particulate organic matter (POM). Macrofauna were collected manually, while benthic

Table 1. Calidris mauri. Capture date, morphological characteristics, and use of individual birds. Sex and maturity status were based on plumage, bill length (Page \& Fearis 1971) and gonads after dissection. Masses were for birds at the moment of sampling on the Roberts Bank stopover on northward migration to the breeding grounds; stopover time (mean $\pm \mathrm{SD}$ ) is $2.2 \pm 1.2 \mathrm{~d}$ (Warnock \& Bishop 1998). A: adult; F: female; J: juvenile; M: male; MO: microscopic observations; PA: pigment analyses; SIA: stable isotope analyses. As morphological measurements were accidentally omitted (nd) for birds 15 and 16, they were not used for isotopic determinations, only for pigment analysis of stomach contents

\begin{tabular}{|c|c|c|c|c|c|c|c|c|}
\hline Bird & $\begin{array}{l}\text { Capture date } \\
\text { (Apr 2004) }\end{array}$ & $\begin{array}{l}\text { Bill length } \\
\text { (mm) }\end{array}$ & $\begin{array}{l}\text { Right tarsus } \\
\text { length (mm) }\end{array}$ & $\begin{array}{l}\text { Mass } \\
(\mathrm{g})\end{array}$ & $\begin{array}{l}\text { Wing chord } \\
(\mathrm{mm})\end{array}$ & $\begin{array}{l}\text { Age } \\
\text { class }\end{array}$ & Sex & Use \\
\hline 1 & 22 & 25.68 & 22.88 & 29.0 & 93.0 & $\mathrm{~J}$ & $\mathrm{~F}$ & PA \\
\hline 2 & 22 & 22.03 & 23.49 & 26.5 & 93.0 & A & M & $\mathrm{PA}$ \\
\hline 3 & 22 & 22.80 & 20.73 & 25.5 & 92.5 & A & M & SIA \\
\hline 4 & 22 & 21.16 & 21.06 & 24.5 & 94.0 & $\mathrm{~J}$ & M & $\mathrm{MO}$ \\
\hline 5 & 22 & 21.91 & 21.70 & 25.5 & 94.0 & A & M & SIA \\
\hline 6 & 22 & 22.89 & 22.38 & 25.5 & 99.0 & A & M & SIA \\
\hline 7 & 22 & 25.12 & 24.58 & 30.0 & 102.5 & A & $\mathrm{F}$ & $\mathrm{PA}$ \\
\hline 8 & 25 & 22.34 & 20.96 & 26.5 & 90.0 & A & M & SIA \\
\hline 9 & 25 & 25.55 & 24.15 & 30.5 & 99.5 & A & $\mathrm{F}$ & SIA \\
\hline 10 & 25 & 22.38 & 21.41 & 28.0 & 97.0 & A & M & SIA \\
\hline 11 & 25 & 25.39 & 23.50 & 25.5 & 99.0 & $\mathrm{~J}$ & $\mathrm{~F}$ & PA \\
\hline 12 & 25 & 22.08 & 22.45 & 28.5 & 94.0 & A & M & PA \\
\hline 13 & 25 & 19.68 & 21.06 & 29.0 & 95.0 & A & M & PA \\
\hline 14 & 25 & 23.53 & 21.28 & 30.0 & 94.5 & $\mathrm{~A}$ & M & $\mathrm{MO}$ \\
\hline 15 & 30 & nd & nd & nd & nd & nd & $\mathrm{F}$ & PA \\
\hline 16 & 30 & nd & nd & nd & nd & nd & $\mathrm{F}$ & PA \\
\hline 17 & 30 & 23.07 & 21.83 & 30.0 & 93.0 & $\mathrm{~A}$ & M & PA \\
\hline 18 & 30 & 25.16 & 22.33 & 30.5 & 99.0 & A & $\mathrm{F}$ & $\mathrm{MO}$ \\
\hline
\end{tabular}


nematodes and copepods were obtained by scraping the upper $1 \mathrm{~cm}$ of mud, and extracted from $2 \mathrm{l}$ of this surficial sediment, using a method based on their migration under light as per Riera et al. (1996). Benthic diatoms were separated from the upper $5 \mathrm{~mm}$ layer of $1 \mathrm{~m}^{2}$ of sediment with visible dense biofilm covering as per Decottignies et al. (2007). It is likely that the entire active diatom biomass was included in this samples, since it is confined to the upper $2 \mathrm{~mm}$ (Méléder et al. 2005). Seawater was collected in $15 \mathrm{l}$ plastic containers.

Taxonomic and pigment analysis of sediment and stomach contents. In order to refine our knowledge of the types of material ingested by western sandpipers upon arrival at Roberts Bank, visual and photosynthetic pigment analyses of stomach contents were performed. The taxonomic (to genus level) composition of the microphytic fraction of surface sediment and of western sandpiper stomach contents at the Roberts Bank stopover were determined after separation and processing for light and scanning electron microscopy. The upper $2 \mathrm{~mm}$ (photic zone) of the 6 sediment cores and the stomach contents of 3 birds were treated using the Ludox HS40 protocol to observe microalgae (Méléder et al. 2005), especially diatoms, and mounted for light photomicrography, using an Olympus AX70 microscope. The same samples of sediment and stomach contents were also processed for scanning electron microscopy (Cannuel \& Beninger 2006), and observed using a JEOL JSM 6400F scanning electron microscope. Taxonomic determinations were carried out using morphological criteria based on the reference works of Tomas (1997) for phytoplankton and Round et al. (1990) for diatoms.

Pigments from the upper $2 \mathrm{~mm}$ of 18 sediment cores and 9 stomach contents were extracted and analysed by HPLC using the technique of Méléder et al. (2003a) adapted from Mantoura \& Llewellyn (1983). This method allows estimations of photosynthetically active microphytobenthic biomass, i.e. chlorophyll (chl) a concentration, and higher level taxonomic composition of this biomass (types and concentration of accessory pigments; see Méléder et al. 2005 for references). The total chl a per stomach was used as a very conservative measure (due to partial degradation) of the amount of biofilm found in the stomach, based on the amount of chl a present per surface unit of biofilm.

Stable isotope analyses (SIA). Preparation of potential trophic sources and physiological compartments: Meio- and macrofauna from the sediment samples were kept alive overnight at the laboratory in $0.2 \mu \mathrm{m}$ filtered water from the sampling site to allow evacuation of gut contents, and dissected from the shells or collected on pre-combusted filters as appropriate. POM and benthic diatoms were obtained by filtration of, respectively, water column seawater and the seawater used to separate diatoms from the sediment, onto pre-combusted GF/F filters until clogged. One sample of liver, pectoralis muscle, and stomach contents was taken from each of the 6 birds used for isotopic study. Animal samples and filters were quickly acidified with $1 \mathrm{M} \mathrm{HCl}$ to remove carbonates, rinsed with ultrapure water, freeze dried and powdered using a mortar and pestle.

Isotope ratio mass spectrometry: Duplicate powdered samples or pieces of filters were sealed in ultraclean tin capsules and analyzed for nitrogen and carbon compositions $\left(\delta^{13} \mathrm{C}\right.$ and $\left.\delta^{15} \mathrm{~N}\right)$, using a Carlo-Erba ${ }^{\circledR}$ NA 2100 elemental analyzer coupled (via a Thermo Finnigan ${ }^{\circledR}$ CONFLO II interface) with a Thermo Finnigan ${ }^{\circledR}$ Delta $\mathrm{S}$ mass spectrometer. Carbon and nitrogen isotope compositions were expressed as standard delta notations (\%o deviations from Vienna Pee Dee Belemnite and atmospheric $\mathrm{N}_{2}$, respectively):

$$
\delta X=\left[\left(R_{\text {sample }} / R_{\text {reference }}\right)-1\right] \times 10^{3}
$$

where $X$ is either ${ }^{13} \mathrm{C}$ or ${ }^{15} \mathrm{~N}$ and $R$ is the corresponding ${ }^{13} \mathrm{C} /{ }^{12} \mathrm{C}$ or ${ }^{15} \mathrm{~N} /{ }^{14} \mathrm{~N}$ ratio. The standard deviation of $200 \delta^{13} \mathrm{C}$ and $\delta^{15} \mathrm{~N}$ working reference measurements was $0.2 \%$ and $0.4 \%$ respectively (glutamic acid, run every 11 samples). Isotope readings were validated when the differences between duplicate capsules of the same sample were $<0.4$ and $0.5 \%$ for carbon and nitrogen compositions respectively; otherwise, the samples were analyzed a second time.

Back-calculation of geographic ranges: Precise identification of the stopover sites at which birds were feeding when they assimilated the natural isotope signatures for the liver and muscle was not feasible, given individual and sex-related differences in migration dynamics (Bishop et al. 2004) as well as inter-annual variation in use of migration stopovers, stopover times and migration speed (Butler et al. 1996, 1997, Clark \& Butler 1999). However, stomach contents, liver and muscle corresponded to an increasing physiological incorporation time lag; so the decreasing turnover rates of these 3 animal compartments allowed the identification of diet components retrospectively over increasing time scales (Hobson \& Clark 1993, EvansOgden et al. 2004). We used the only available turnover data for birds (quail, Hobson \& Clark 1992), based on the observation that these times are virtually identical for blood in small-size birds (Hobson \& Clark 1992, Evans-Ogden et al. 2004). For migrating western sandpiper, these compartments, and their corresponding time scales, represented diets at progressively more distant geographic ranges: stomach contents, for the Roberts Bank stopover diet (R), liver (half residency time $2.6 \mathrm{~d}$ in quail), for diets on recent migratory stopovers (proximal stopovers, PS), and muscle (half 
residency time $12.4 \mathrm{~d}$ in quail), for diets on further previous stopovers (distal stopovers, DS). We combined the isotopic turnovers of the physiological compartments with monitoring data from radio-marked western sandpiper (Baird 2010) to calculate the geographical ranges corresponding to each compartment's isotopic signature. We conservatively chose a window of 1 to $5 \mathrm{~d}$ to cover the turnover time of most of the liver tissue, and 5 to $20 \mathrm{~d}$ to cover the turnover time of most of the muscle tissue. Based on these windows, and known migration routes of western sandpiper (Warnock \& Bishop 1998), the birds could have been feeding at sites from the Roberts Bank stopover to California 1 to $5 \mathrm{~d}$ before collection (equivalent to the diet indicated in the liver signatures and referred to as PS in the text) and from California to Mexico in the 5 to $20 \mathrm{~d}$ window (equivalent to diet indicated by the muscle signatures, and referred to as DS in the text). These ranges are shown in Fig. 1. Shorter or longer actual turnover times would place the pre-Roberts Bank stopovers closer or further away, but would not alter conclusions concerning eventual differences in the diets prior to and at the Roberts Bank stopover.

Estimation of diets and trophic positions: Calculated diet isotopic compositions were obtained by subtracting the available trophic enrichment factors for Calidris alpina, a closely-related species which also appears capable of biofilm feeding (Elner et al. 2005), of 1.9 and $3.1 \%$ for muscle, and 1.1 and $4 \%$ for liver (Evans-Ogden et al. 2004) from carbon and nitrogen deviations, respectively. In accordance with the general consensus that primary consumers provide the most appropriate isotopic baseline (Post 2002), we chose Mya sp. and Tapes philippinarum as the food base at the Roberts Bank stopover. The tissues of these 2 suspension-feeding bivalves (SFB) were pooled due to their shared habitat and feeding habit, reinforced by the ANOVA $(p>0.9)$ and $\mathrm{NND}^{2}(\mathrm{p}<0.01)$ values (see below 'Statistical analysis'). Diet of the infaunal SFBs Mya sp. and Tapes philippinarum was estimated using enrichment factors of -0.90 to 2.04 and 1.14 to $5.40 \%$ for carbon and nitrogen, respectively. In accordance with the general consensus that primary consumers provide the most appropriate isotopic baseline (Post 2002), we chose Mya sp. and Tapes philippinarum as food base at the Roberts Bank stopover. This range reflected the variability of literature values (Post 2002, Yokoyama et al. 2005, 2008, Dubois et al. 2007). Recently developed mixing models accounting for uncertainty associated with multiple sources, fractionation and isotope compositions, MixSIR and SIAR (Moore \& Semmens 2008, Parnell et al. 2008, Jackson et al. 2009), were used to estimate source contributions to western sandpiper and SFB diets at the Roberts Bank stopover. Food source isotope deviations were inputs to these models, which calculate feasible source combinations that explain observed consumer isotopic compositions, for each of the physiological compartments and their corresponding geographical windows. For MixSIR results, the maximum importance ratio was below 0.001, indicating model effectiveness in estimating true posterior density (Moore \& Semmens 2008). MixSIR results were presented as mode, 5th and 95th percentiles. SIAR is an $\mathrm{R}$ freeware package ( $\mathrm{R}$ Development Core Team 2008). A standard size and a long size SIAR run were used to determine, respectively, western sandpiper and SFB diets, without small $(<0.01)$ p-values. Results are reported as mode, low and high 95\% highest density regions (also called highest posterior density), and probability distributions.

Western sandpiper trophic position (TP, Post 2002) was estimated for the 3 geographical locations as:

$$
\mathrm{TP}_{\mathrm{x}}=\lambda+\frac{\left(\delta^{15} \mathrm{~N}_{\mathrm{c}}-\delta^{15} \mathrm{~N}_{\text {base }}\right)}{\Delta_{\mathrm{n}}}
$$

where $x$ is either R, PS or DS, $\delta^{15} N_{c}$ is the mean nitrogen isotopic composition of the corresponding animal compartment i.e. liver including stomach contents values (assuming incorporation first into liver tissue), liver alone, or muscle; $\lambda$ is the trophic position of the food base ( 1 for primary producers, 2 for primary consumers, etc) $\delta^{15} \mathrm{~N}_{\text {base }}$ is the mean nitrogen isotopic composition of the food base; and $\Delta_{\mathrm{n}}$ is the mean trophic level fractionation of $\delta^{15} \mathrm{~N}$ generally assumed through the trophic chains (3.4 $\pm 1.0 \%$, mean \pm SD; Post 2002). To assess errors associated with the use of SFB as baseline for all compartments, or with the mean isotopic compositions and fractionation, we used a first-order Taylor series approximation of the variance of $\mathrm{TP}_{x}$ using partial derivatives (Phillips \& Gregg 2001a, b):

$$
\sigma_{\mathrm{TP}_{x}}^{2}=\left(\frac{\partial_{\mathrm{TP}_{x}}}{\partial_{\delta^{15} \mathrm{~N}_{\mathrm{c}}}}\right)^{2} \sigma_{\delta^{15} \mathrm{~N}_{\mathrm{c}}}^{2}+\left(\frac{\partial_{\mathrm{TP}_{x}}}{\partial_{\delta^{15} \mathrm{~N}_{\text {base }}}}\right)^{2} \sigma_{\delta^{15} \mathrm{~N}_{\text {base }}}^{2}+\left(\frac{\partial_{\mathrm{TP}_{x}}}{\partial_{\Delta_{\mathrm{n}}}}\right)^{2} \sigma_{\Delta_{\mathrm{n}}}^{2}
$$

After substitution with derivatives, this yields:

$$
\sigma_{\mathrm{TP}_{x}}^{2}=\left(\frac{1}{\Delta_{\mathrm{n}}}\right)^{2} \sigma_{\delta^{15} \mathrm{~N}_{\mathrm{c}}}^{2}+\left(-\frac{1}{\Delta_{\mathrm{n}}}\right)^{2} \sigma_{\delta^{15} \mathrm{~N}_{\text {base }}}^{2}+\left(\frac{\delta^{15} \mathrm{~N}_{\text {base }}-\delta^{15} \mathrm{~N}_{\mathrm{c}}}{\Delta_{\mathrm{n}}^{2}}\right)^{2} \sigma_{\Delta_{\mathrm{n}}}^{2}
$$

which may be simplified to:

$$
\sigma_{\mathrm{TP}_{\mathrm{x}}}^{2}=\left(\frac{1}{\Delta_{\mathrm{n}}}\right)^{2}\left(\sigma_{\delta^{15} \mathrm{~N}_{\mathrm{c}}}^{2}+\sigma_{\delta^{15} \mathrm{~N}_{\text {base }}}^{2}+\left(\frac{\delta^{15} \mathrm{~N}_{\text {base }}-\delta^{15} \mathrm{~N}_{\mathrm{c}}}{\Delta_{\mathrm{n}}}\right)^{2} \sigma_{\Delta_{\mathrm{n}}}^{2}\right)
$$

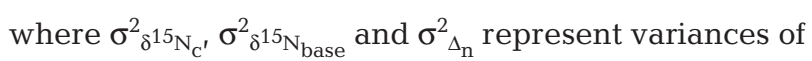
the corresponding means described above.

Statistical analysis: The squared nearest neighbor distances (NND ${ }^{2}$, Lubetkin \& Simenstad 2004) were calculated to determine whether the isotopic deviations of the potential sources were distinct or required pooling. SigmaStat 3.11.0 was used to run 2 one-way para- 
metric ANOVAs on normally distributed, homoscedastic carbon and nitrogen isotopic deviations between the different physiological compartments.

\section{RESULTS}

\section{Benthic diatoms and pigments in sediment and stomach contents}

A diverse and generally intact diatom assemblage was observed in the sediment biofilm and in the stomach contents. Assemblages were highly similar in both sample types (Table 2). A total of 24 chlorophyll and carotenoid pigments were identified in the sediment biofilm samples (Table 3). Seven major pigments (greatest peak areas) were found in all samples: fucoxanthin, diadinoxanthin, chl $c 1$ and $c 2$, chlorophyllide $a$, chl $a$ and diatoxanthin. Seventeen pigments were present in at least $80 \%$ of samples.

These 24 pigments were also identified in the stomach contents samples, plus 3 additional ones, and 21 out of 27 had frequencies of occurrence $>80 \%$ (Table 3 ). Major pigments were chl $a$, chl $b$, chl $c 1$ and $c 2$, diadinoxanthin, diatoxanthin, unidentified carotenoids, crocoxanthin, and $\beta \beta$ carotene.

Some combinations of pigments constitute taxonomic markers of biofilm components: Chl $c 1$ and c2 and fucoxanthine are specific to diatoms; diadinoxanthine and diatoxanthine are both indicators of diatoms and euglenophytes, and chl $b$ and luteine both indicate chlorophytes and macroalgal debris (Jeffrey et al. 1997, Méléder et al. 2005). Degradation products (phaeophytins $a$ and $b$,

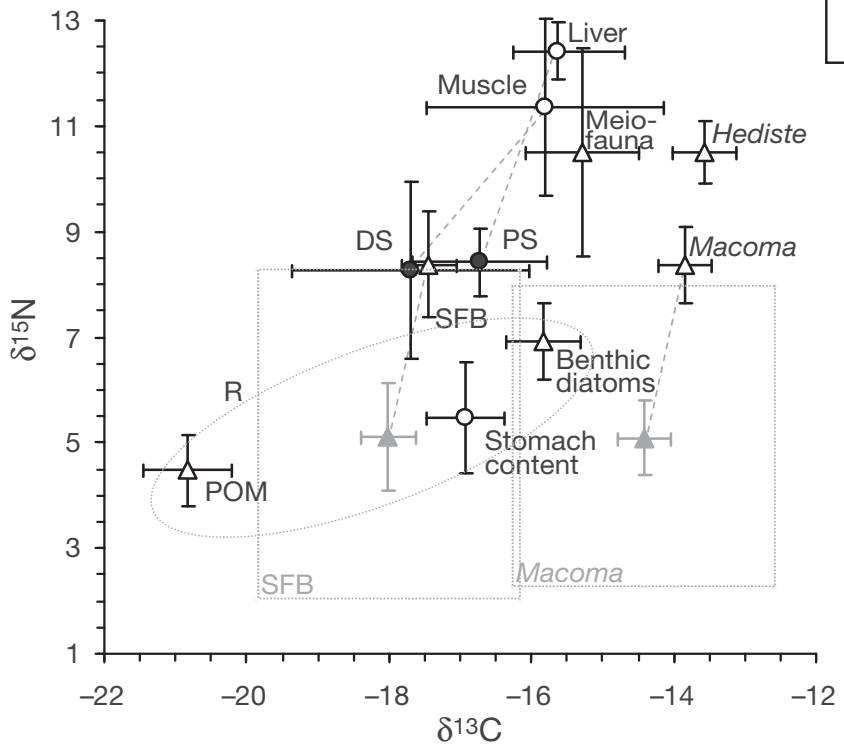

Table 2. Major taxonomic groupings and genera of diatoms (Bacillariophyta) observed in sediment and stomach contents of western sandpiper at Roberts Bank stopover, April 2004

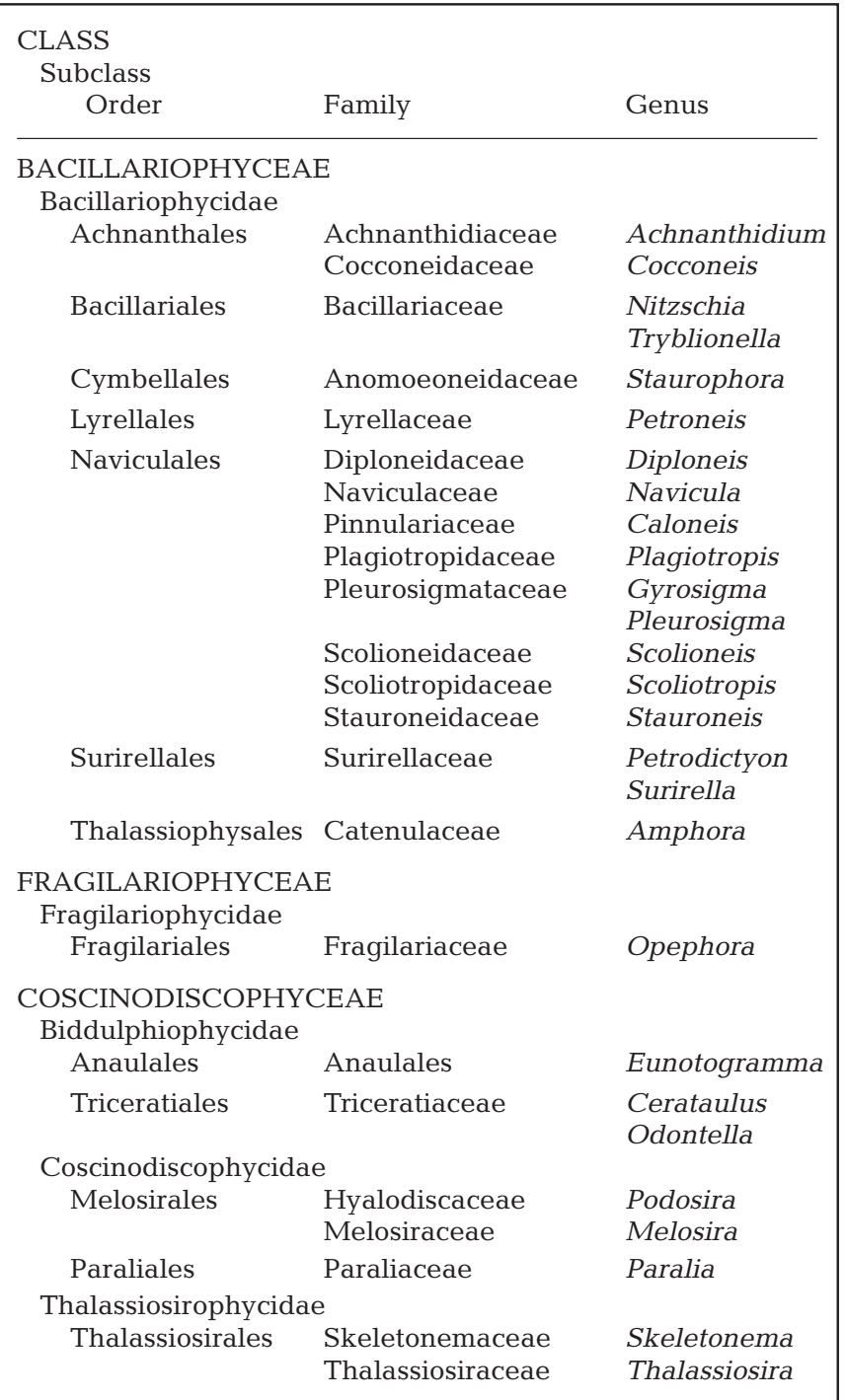

Fig. 2. $\delta^{13} \mathrm{C}$ and $\delta^{15} \mathrm{~N}(\%)$ of potential food sources $(\Delta)$ and western sandpiper compartments $(\mathrm{O})$. Means \pm SD. Dietary isotopic values $(\bullet)$ were obtained by subtracting trophic enrichment (dashed lines) of 1.9 and $3.1 \%$ for muscle, and 1.1 and $4 \%$ for liver (Evans-Ogden et al. 2004) from carbon and nitrogen deviations, respectively. The ellipse groups together the sources at Roberts Bank stopover which contributed to diet. The $\Delta$ and rectangles represent the ranges of possible diet isotopic deviations of suspension-feeding bivalves (SFB: Mya sp. and Tapes philippinarum) and Macoma sp., taking into account the range of published fractionation values ( -0.90 to 2.04 and 1.14 to $5.40 \%$ for carbon and nitrogen, respectively; Post 2002, Yokoyama et al. 2005, 2008, Dubois et al. 2007). Only isotopic composition of liver vs. muscle was not statistically significant (ANOVA, p > 0.05). POM: particulate organic matter; R: Roberts Bank stopover; PS: proximate stopovers; DS: distal stopovers 
Table 3. HPLC from biofilm $(\mathrm{B}, \mathrm{n}=18)$ and western sandpiper stomach contents $(\mathrm{SC}, \mathrm{n}=9)$. Elution order, retention time (RT) and frequency of occurrence (FO) of pigments

\begin{tabular}{|c|c|c|c|c|}
\hline \multirow{3}{*}{$\begin{array}{l}\text { Peak no. } \\
\text { at } 440 \mathrm{~nm} \\
1\end{array}$} & \multirow{3}{*}{$\begin{array}{l}\text { Pigment } \\
\text { Chlorophyllide } b\end{array}$} & \multirow{3}{*}{$\begin{array}{c}\begin{array}{c}\mathrm{RT} \\
(\mathrm{min})\end{array} \\
2.4\end{array}$} & \multicolumn{2}{|c|}{$-\mathrm{FO}(\%)-$} \\
\hline & & & B & $\mathrm{SC}$ \\
\hline & & & 78 & 11 \\
\hline 2 & Chlorophyllide $a$ & 3.4 & 100 & 67 \\
\hline 3 & $\mathrm{Chl} C_{1}+C_{2}$ & 4.6 & 100 & 100 \\
\hline 4 & $\mathrm{Chl} C_{3}$ & 5.6 & 100 & 100 \\
\hline 5 & Siphonaxanthin & 7.4 & 100 & 100 \\
\hline 6 & Unknown carotenoid 1 & 7.9 & 89 & 89 \\
\hline 7 & Fucoxanthin & 8.5 & 100 & 100 \\
\hline 8 & Unknown carotenoid 2 & 9.3 & 100 & 44 \\
\hline 9 & Pheophorbide $a$ & 9.7 & 100 & 100 \\
\hline 10 & Prasinoxanthin-like & 10.4 & 100 & 33 \\
\hline 11 & Diadinoxanthin & 10.6 & 100 & 100 \\
\hline 12 & Diadinochrome & 10.9 & 89 & 100 \\
\hline 13 & Alloxanthine & 11.4 & 100 & 100 \\
\hline 14 & Diatoxanthin & 11.7 & 100 & 100 \\
\hline 15 & Unknown carotenoid 3 & 12.0 & 100 & 100 \\
\hline 16 & Unknown carotenoid 4 & 12.3 & 0 & 89 \\
\hline 17 & Lutein & 12.8 & 100 & 100 \\
\hline 18 & Zeaxanthin & 13.4 & 0 & 89 \\
\hline 19 & Unknown carotenoid 5 & 14.2 & 33 & 89 \\
\hline 20 & Chl $b$ & 14.8 & 83 & 100 \\
\hline 21 & Crocoxanthin & 15.3 & 11 & 100 \\
\hline 22 & Chl a & 15.8 & 100 & 100 \\
\hline 23 & Pheophytin $b$ & 16.6 & 22 & 100 \\
\hline 24 & $\varepsilon \varepsilon$-carotene & 17.3 & 28 & 78 \\
\hline 25 & Pheophytin a & 18.3 & 28 & 89 \\
\hline 26 & $\beta \beta$-carotene & 19.2 & 50 & 100 \\
\hline 27 & Pyropheophytin a & 21.1 & 0 & 22 \\
\hline
\end{tabular}

pyrophaeophytin $a_{1}$ diadinochrome, unidentified carotenoids 4 and 5) were detected at higher levels in the stomach contents than in sediment biofilm samples. These products are typically found in the feces of algal grazers (Gieskes et al. 1991, Abele-Oeschger et al. 1992, Cartaxana et al. 2003).

$\mathrm{Chl}$ a concentration in the biofilm ranged from 1.4 to $42.1 \mathrm{mg} \mathrm{m}^{-2}$ with means $( \pm \mathrm{SD})$ of $20.5 \pm 14.8,3.7 \pm 2.6$ and $4.4 \pm 2.5 \mathrm{mg} \mathrm{m}^{-2}$ on 22,25 and 30 April respectively, corresponding to different amounts of photosynthetically active biomass in the photic zone (the upper $2 \mathrm{~mm}$ of sediment, Méléder et al. 2005). Western sandpiper stomachs contained a mean $( \pm \mathrm{SD})$ of $1.0 \pm 0.7 \mu \mathrm{g}$ chl $a$, corresponding to $1.3 \pm 0.9 \mathrm{~cm}^{2}$ (ranging from 0.2 to $11.8 \mathrm{~cm}^{2}$ ) of sediment biofilm surface.

\section{Stable isotope analyses}

Fig. 2 shows the $\delta^{13} \mathrm{C}$ and $\delta^{15} \mathrm{~N}$ values for the potential food sources (SFB and Macoma sp.) and for the stomach contents, liver, and muscle of the sampled western sandpipers at the Roberts Bank stopover. Fig. 2 shows the major diet components corresponding

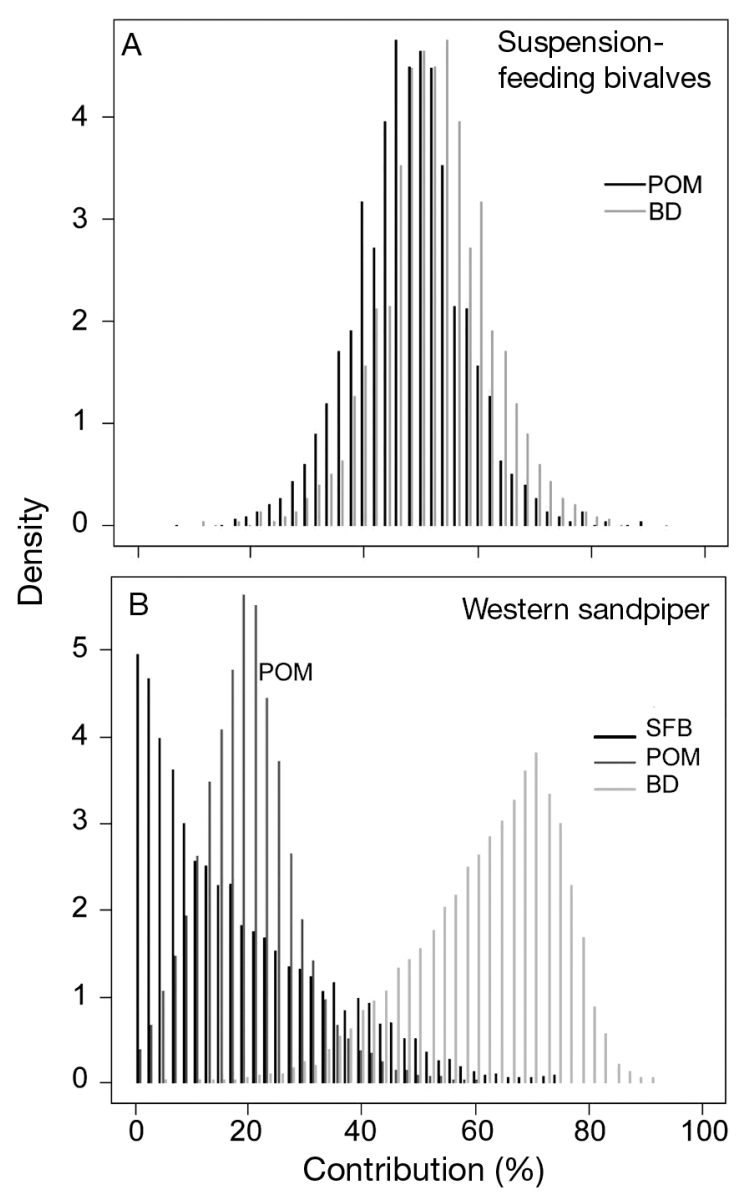

Fig. 3. Probability distributions of contributions of potential food sources in diets of (A) suspension-feeding bivalves (SFB) and (B) western sandpiper at Roberts Bank stopover obtained using the SIAR mixing model. BD: benthic diatoms; POM: particulate organic matter. The highest probability contributions for the SFB diet are $50 \%$ POM and $50 \%$ BD, whereas the highest probability contributions for the western sandpiper diet were $>75 \% \mathrm{BD}, 20 \% \mathrm{POM}$, and $<5 \% \mathrm{SFB}$

to the isotopic composition of each animal compartment, which in turn reflects that of the 3 major geographical localities: R, PS and DS. Neither the liver and muscle isotopic compositions nor those of the corresponding calculated diets were significantly different (ANOVA, $p$ > 0.05). Notwithstanding, Fig. 2 demonstrates a dietary shift from PS and DS to R, confirmed by the calculation of trophic positions. With an estimated TP of $3.0 \pm 0.5($ mean $\pm \mathrm{SD}$ ) the PS and DS diets appear most closely related to the isotopic compositions found in the SFB tissues (Fig. 2). The depositfeeding bivalve Macoma sp. (Rossi et al. 2004) is well outside any diet ellipse, indicating either negative prey selection, capture inability, or the absence of bivalves with a similar ${ }^{13} \mathrm{C}$-depleted diet on the previous stopover grounds. The R diet indicated by the ellipse in Fig. $2(\mathrm{TP}=2.3 \pm 0.4)$ is close to the SFB $\operatorname{diet}(\mathrm{TP}=2)$, 
Table 4. Estimates of the contribution of potential food sources to the diets of western sandpiper and of the suspension-feeding bivalves (SFB: Mya sp. and Tapes philippinarum) at Roberts Bank stopover using MixSIR and SIAR mixing models. Modes and low-high 95\% highest density regions (SIAR) or 5-95\% percentiles (MixSIR) are presented.

BD: benthic diatoms; POM: particulate organic matter

\begin{tabular}{|c|c|c|c|c|}
\hline \multirow[t]{2}{*}{ Consumers } & \multirow{2}{*}{$\begin{array}{c}\text { Mixing } \\
\text { model }\end{array}$} & \multicolumn{3}{|c|}{ —Dietary contribution (\%) } \\
\hline & & SFB & POM & BD \\
\hline \multirow{2}{*}{$\begin{array}{l}\text { Western } \\
\text { sandpiper }\end{array}$} & MixSIR & $1(0-4)$ & $24(18-29)$ & $75(70-81)$ \\
\hline & SIAR & $4(0-47)$ & $20(2-37)$ & $70(37-83)$ \\
\hline \multirow[t]{2}{*}{ SFB } & MixSIR & - & $47(32-62)$ & $53(38-68)$ \\
\hline & SIAR & - & $49(28-67)$ & $51(33-72)$ \\
\hline
\end{tabular}

but distant from that of Macoma sp. The mixing models MixSIR and SIAR both identified that western sandpiper obtained a large proportion of their energy requirements from benthic diatoms $(\sim 70 \%)$ and settled suspended particulate organic matter $(\sim 20 \%)$, as did the SFB (although the proportion of benthic diatoms was much higher, and that of POM much lower, in western sandpiper - Table 4 \& Fig. 3). The diets corresponding to the 3 geographical localities (R, PS and DS) are summarized in Fig. 4.

\section{DISCUSSION}

The high degree of homogeneity in the biofilm photopigment assemblages of the 18 samples analyzed suggested a high degree of spatial taxonomic homogeneity in the algal component of microphytobenthos at the Roberts Bank stopover, consistent with previous findings on mudflats (Guarini et al. 1998, Haubois et al. 2005). The microscopic determinations and photopigment taxonomic markers revealed that the algal component consisted largely of benthic diatoms. As previously noted by Kuwae et al. (2008), all photopigments

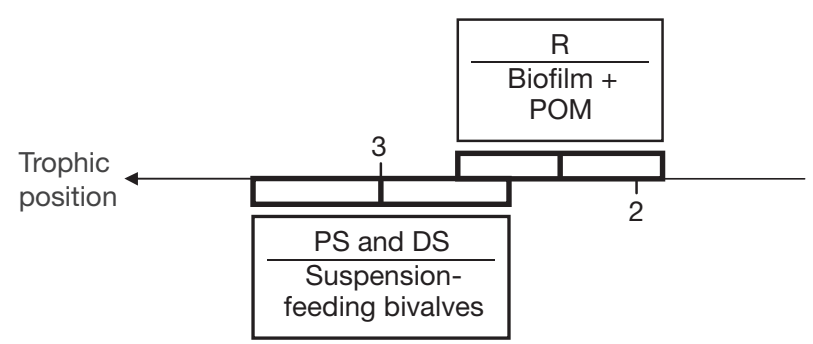

Fig. 4. Calidris mauri. Major components of western sandpiper diets and trophic positions at proximate and distal stopover grounds (PS and DS) prior to arrival at Roberts Bank stopover (R), as given by the $\delta^{13} \mathrm{C}$ and $\delta^{15} \mathrm{~N}$ of muscle (DS), liver (PS), and stomach contents (R). Bold rectangles represent $\mathrm{SD}$ of the means identified in sediment samples were evident in the stomach contents and several of the identified products are typically found in the feces of algal grazers (Gieskes et al. 1991, Abele-Oeschger et al. 1992, Cartaxana et al. 2003). The amount of biofilm ingested was unlikely to be the result of accidental ingestion (Kuwae et al. 2008, Mathot et al. 2010).

The isotopic results of the present study demonstrated a migratory downward dietary shift as western sandpipers migrated northwards (Fig. 4). The differences in $\delta^{15} \mathrm{~N}$ values between animal compartments (and hence stopover sites) translated to about 0.75 trophic levels. We are unaware of any other study which has demonstrated such a downward migratory trophic shift. The dietary shift observed in the present study was probably not due to a dearth of potential macrofaunal prey, as these are abundant on Roberts Bank at this time of year (Sutherland et al. 2000, Mathot et al. 2007).

The partial overlap observed between the trophic levels corresponding to PS and RS (combined results) and R (Fig 4) indicates a progressive shift to lower trophic levels over the northward migration, rather than a sudden dietary changeover. Such a progressive shift would favor the type of physiological transition associated with changes in digestive enzyme activities. The digestive enzyme activities of western sandpiper vary with season (Stein et al. 2005), although no study has yet examined this during the northward migration from the overwintering grounds.

Clearly, biofilm cannot simply represent a 'better than nothing' feeding strategy, since alternate food sources were available (in particular benthic macrofauna, as noted above). Moreover, morphological adaptations of the western sandpiper tongue allow feeding on biofilm (Elner et al. 2005), indicating a specialized apomorphic character. Clues to the possible utility of biofilm feeding may lie in the small volume of the western sandpiper stomach $(\leq 1 \mathrm{ml})$, which does not permit large intakes of food even if large quantities are available. Under such constraints, the high-carbohydrate biofilm (Characklis \& Marshall 1989, Smith \& Underwood 2000) may provide more energy more quickly for migration than the higher-protein macrofaunal diet of the overwintering grounds, where the birds have time to feed at a slower pace. Handling time, travel time to patch (spatial distribution of potential food), and consistency of food quality are also potentially important factors in the context of optimal foraging theory constraints (Krebs \& Davies 1997). Regarding the latter consideration, although data on small macrofaunal energy contents are lacking, it should be noted that adult SFB vary greatly in energy content, with minimum values for Tapes philippinarum equivalent to those of biofilm, and maximum values 6 
times those of biofilm, depending on physiological condition (Beninger \& Lucas 1984, Kuwae et al. 2008). However, handling time is probably much greater for the SFB prey. In addition, macroinfaunal distribution, abundance, and recruitment are largely cryptic and may be extremely variable (Beukema \& de Vlas 1989, Beukema et al. 1993, Zwarts \& Wanink 1993, Honkoop et al. 2006, Van der Wal et al. 2008, Chapman et al. 2010), whereas microphytobenthic patches are much more visible and, notwithstanding small-scale spatial variability (Murphy et al. 2008, Chapman et al. 2010), spatially predictable (e.g. following precise high tide isobaths, Méléder et al. 2003b). Given their small size $(\sim 30 \mathrm{~g})$, western sandpipers are likely to adopt an 'income', rather than a 'capital' trophic strategy before breeding (Drent \& Daan, 1980, Bonnet et al. 1998), so these considerations are likely to be acutely important.

Biofilm feeding may also reduce interspecies competition for macrofaunal food (as suggested by Kuwae et al. 2008). Further elucidation of adaptive value of this diet shift requires more precise knowledge of the chemical composition of the complex matrix that constitutes intertidal biofilm (Duke \& Reimann 1977, Volcani 1981, Smith \& Underwood 2000, Cigleneãki et al. 2003), and especially the energy, and array of nutrients, vitamins and minerals available therein, relative to macrofauna, as well as a better knowledge of the physiological requirements of western sandpiper at this stage of migration.

Several exciting perspectives have been opened by the discovery of intertidal biofilm feeding by western sandpipers and their migratory diet shift. Beyond the search for similar processes in other shorebird species, ontogenetic study of feeding and tongue morphology would probably shed light on the acquisition of the biofilm feeding mode, and perhaps provide clues to the evolution of this character. In the geochemical and physical realms, the effects of western sandpiper intertidal biofilm grazing on sediment stability and erosion (Sutherland et al. 1998a,b, Lundkvist et al. 2007) across the migratory routes should be quantified, as should the dynamics of biofilm production and consumption on the mudflat ecosystem scale, and the resulting export of primary production from this ecosystem.

Acknowledgements. We thank Richard Robins for help with SIA, and Rodolphe Turpeau and Bruno Cognie for verification of partial derivative equations.

\section{LITERATURE CITED}

Abele-Oeschger D, Szaniawska A, Theede H (1992) Do pigments reflect the turnover of plant material in food chain studies? Analysis of plant pigments in the intestine of Saduria (Mesidotea) entomon. Mar Ecol Prog Ser 81: 43-49
Arthur KE, Boyle MC, Limpus CJ (2008) Ontogenetic changes in diet and habitat use in green sea turtle (Chelonia mydas) life history. Mar Ecol Prog Ser 362:303-311

Arzel C, Elmberg J, Guillemain M (2006) Ecology of spring migrating Anatidae: a review. J Ornithol 147:167-184

Baird P (2010) A multinational study of neotropical migrants, the western sandpiper as an example, 2004-2008. Project no. 03-199 to 07-199, final report to the US Department of Defense, Legacy Resource Management Program, Washington, DC. www.kahiltna.org/assets/reports/Neotropical_Migrants.pdf

Beninger PG, Lucas L (1984) Seasonal variations in condition, reproductive activity, and gross biochemical composition of two species of adult clam reared in a common habitat: Tapes decussatus (Jeffreys) and Tapes philippinarum (Adams and Reeve). J Exp Mar Biol Ecol 79:19-37

Beukema J, de Vlas J (1989) Tidal-current transport of threaddrifting postlarval juveniles of the bivalve Macoma balthica from the Wadden Sea to the North Sea. Mar Ecol Prog Ser 52:193-200

Beukema JJ, Essink K, Michaelis H, Zwarts L (1993) Year-toyear variability in the biomass of macrobenthic animals on tidal flats of the Wadden Sea: How predictable is this food source for birds? Neth J Sea Res 31:319-330

Bishop MA, Warnock N, Takekawa JY (2004) Differential spring migration by male and female western sandpipers at interior and coastal stopover sites. Ardea 92:185-196

Bonnet X, Bradshaw D, Shine R (1998) Capital versus income breeding: an ectothermic perspective. Oikos 83:333-364

Butler RW, Kaiser GW, Smith GEJ (1987) Migration chronology, length of stay, sex ratio, and weight of western sandpiper (Calidris mauri) on the south coast of British Columbia. J Field Ornithol 58:103-111

Butler RW, Delgado FS, De La Cueva H, Pulido V, Sandercock BK (1996) Migration routes of the western sandpiper. Wilson Bull 108:662-672

Butler RW, Williams TD, Warnock N, Bishop MA (1997) Wind assistance: a requirement for migration of shorebirds? Auk 114:456-466

Cannuel R, Beninger PG (2006) Gill development, functional and evolutionary implications in the Pacific oyster Crassostrea gigas (Bivalvia: Ostreidae). Mar Biol 149: 547-563

Cartaxana P, Jesus B, Brotas V (2003) Pheophorbide and pheophytin a-like pigments as useful markers for intertidal microphytobenthos grazing by Hydrobia ulvae. Estuar Coast Shelf Sci 58:293-297

> Chapman MG, Tolhurst TJ, Murphy RJ, Underwood AJ (2010) Complex and inconsistent patterns of variation in benthos, micro-algae and settlement over multiple spatial scales. Mar Ecol Prog Ser 398:33?47

Characklis WG, Marshall KC (1989) Biofilms. Wiley, New York, NY

> Ciglenečki I, Plavšic M, Vojvodic V, Cosovic B, Pepi M, Baldi F (2003) Mucopolysaccharide transformation by sulfide in diatom cultures and natural mucilage. Mar Ecol Prog Ser 263:17-27

Clark CW, Butler RW (1999) Fitness components of avian migration: a dynamic model of western sandpiper migration. Evol Ecol Res 1:443-457

> Dalerum F, Angerbjörn A (2005) Resolving temporal variation in vertebrate diets using naturally occuring stable isotopes. Oecologia 144:647-658

> Decottignies P, Beninger PG, Rincé Y, Robins RJ, Riera P (2007) Exploitation of natural food sources by two sympatric, invasive suspension-feeders: Crassostrea gigas and Crepidula fornicata. Mar Ecol Prog Ser 334:179-192 
Drent RH, Daan S (1980) The prudent parent: energetic adjustments in avian breeding. Ardea 68:225-252

- Dubois S, Blin JL, Bouchaud B, Lefebvre S (2007) Isotope trophic-step fractionation of suspension-feeding species: implications for food partitioning in coastal ecosystems. J Exp Mar Biol Ecol 351:121-128

Duke EL, Reimann BEF (1977) The ultrastructure of the diatom cell. In: Werner D (ed) The biology of diatoms. Bot Monogr Vol XIII. University of California Press, Berkeley, CA, p 65-109.

Eldridge J (1992) Management of habitat for breeding and migrating shorebirds in the Midwest., Leaflet 13, Waterfowl management handbook. US Fish and Wildlife Service, Washington, DC

Elner RW, Beninger PG, Jackson DL, Potter TM (2005) Evidence of a new feeding mode in western sandpiper (Calidris mauri) and Dunlin (Calidris alpina) based on bill and tongue morphology and ultrastructure. Mar Biol 146: 1223-1234

Evans-Ogden LJ, Hobson KA, Lank DB (2004) Blood isotopic $\left(\delta^{13} \mathrm{C}\right.$ and $\left.\delta^{15} \mathrm{~N}\right)$ turnover and diet-tissue fractionation factors in captive dunlin (Calidris alpina pacifica). Auk 121: 170-177

Gieskes WWC, Engelkes MM, Kraay GW (1991) Degradation of diatom chlorophyll to colourless, non-fluorescing compounds during copepod grazing. Hydrobiol Bull 25:65-72

Guarini JM, Blanchard GF, Bacher C, Gros P and others (1998) Dynamics of spatial patterns of microphytobenthic biomass: inferences from a geostatistical analysis of two comprehensive surveys in Marennes-Oléron Bay (France). Mar Ecol Prog Ser 166:131-141

Haubois AG, Sylvestre F, Guarini JM, Richard P, Blanchard GF (2005) Spatio-temporal structure of the epipelic diatom assemblage from an intertidal mudflat in MarennesOléron Bay, France. Estuar Coast Shelf Sci 64:385-394

Hobson KA, Clark RG (1992) Assessing avian diets using stable isotopes I: turnover of ${ }^{13} \mathrm{C}$ in tissues. Condor 94: 181-188

Hobson KA, Clark RG (1993) Turnover of ${ }^{13} \mathrm{C}$ in cellular and plasma fractions of blood: implications for nondestructive sampling in avian dietary studies. Auk 110:638-641

Honkoop PJC, Pearson GB, Lavaleye MSS, Piersma T (2006) Spatial variation of the intertidal sediments and macrozoobenthic assemblages along Eighty-mile Beach, Northwestern Australia. J Sea Res 55:278-291

> Huettmann F, Czech B (2006) The steady-state economy for global shorebird and habitat conservation. Endang Species Res 2:89-92

Jackson AL, Inger R, Bearhop S, Parnell A (2009) Erroneous behaviour of MixSIR, a recently published Bayesian isotope mixing model: a discussion of Moore \& Semmens (2008). Ecol Lett 12:E1-E5

Jeffrey SW, Mantoura RFC, Wright SW (1997) Phytoplankton pigments in oceanography: guidelines to modern methods. Monographs on oceanographic methodology, 10. UNESCO, Paris

> Jing Z, Kai J, Xiaojing G, Zhijun M (2007) Food supply in intertidal area for shorebirds during stopover at Chongming Dongtan, China. Acta Ecol Sin 27:2149-2159

Kelly JF (2000) Stable isotopes of carbon and nitrogen in the study of avian and mammalian trophic ecology. Can J Zool 78:1-27

Krebs JR, Davies NB (1997) Behavioural ecology: an evolutionary approach, 4th edn.Wiley-Blackwell, Hoboken, NJ

Kuwae T, Beninger PG, Decottignies P, Mathot KJ, Lund DR, Elner RW (2008) Biofilm grazing in a higher vertebrate: the western sandpiper, Calidris mauri. Ecology 89:599-606
Kvist A, Lindstrom A (2003) Gluttony in migratory wadersunprecedented energy assimilation rates in vertebrates. Oikos 103:397-402

> Lubetkin SC, Simenstad CA (2004) Multi-source mixing models to quantify food web sources and pathways. J Appl Ecol 41:996-1008

Lundkvist M, Gangelhof U, Lunding J, Flindt MR (2007) Production and fate of extracellular polymeric substances produced by benthic diatoms and bacteria: a laboratory study. Estuar Coast Shelf Sci 75:337-346

Mantoura RFC, Llewellyn CA (1983) The rapid determination of algal chlorophyll and carotenoid pigments and their breakdown products in natural waters by reverse-phase high-performance liquid chromatography. Anal Chim Acta 151:297-314

Mathot KJ, Smith BD, Elner RW (2007) Latitudinal clines in food distribution correlate with differential migration in the western sandpiper. Ecology 88:781-791

Mathot KJ, Lund DR, Elner RW (2010) Sediment in stomach contents of western sandpiper and Dunlin provide evidence of biofilm feeding. Waterbirds 33:300-306

Mawhinney K, Hicklin PW, Boates JS (1993) A re-evaluation of the numbers of migrant semipalmated sandpipers, Calidris pusilla, in the Bay of Fundy during fall migration. Can Field Nat 107:19-23

Méléder V, Barillé L, Launeau P, Carrère V, Rincé Y (2003a) Spectrometric constraint in analysis of benthic diatom biomass using monospecific cultures. Remote Sens Environ 88:386-400

Méléder V, Launeau P, Barillé L, Rincé Y (2003b) Cartographie des peuplements du microphytobenthos par télédétection visible-infrarouge dans un écosystème conchylicole. C R Biol 326:377-389

Méléder V, Barillé L, Rincé Y, Morançais M, Rosa P, Gaudin P (2005) Spatiotemporal changes in microphytobenthos structure analysed by pigment composition in a macrotidal flat (Bourgneuf Bay, France). Mar Ecol Prog Ser 297: 83-99

Moore JW, Semmens BX (2008) Incorporating uncertainty and prior information into stable isotope mixing models. Ecol Lett 11:470-480

Murphy RJ, Tolhurst TJ, Chapman MG, Underwood AJ (2008) Spatial variation of chlorophyll on estuarine mudflats determined by field-based remote sensing. Mar Ecol Prog Ser 365:45-55

- Oppel S, Powell AN (2009) Carbon isotope turnover in blood as a measure of arrival time in migratory birds using isotopically distinct environments. J Ornithol 151:123-131

Page G, Fearis B (1971) Sexing western sandpiper by bill length. Bird Banding 42:297-298

Parnell A, Inger R, Bearhop S, Jackson AL (2008) SIAR: Stable Isotope Analysis in R. cran.r-project.org/web/packages/ siar/index.html

> Phillips DL, Gregg JW (2001a) Uncertainty in source partitioning using stable isotopes. Oecologia 127:171-179

> Phillips DL, Gregg JW (2001b) Uncertainty in source partitioning using stable isotopes Erratum. Oecologia 128:304

Piersma T, Lindström A (2004) Migrating shorebirds as integrative sentinels of global environmental change. Ibis 146(Suppl 1):61-69

Podlesak DW, McWilliams SR, Hatch KA (2005) Stable isotopes in breath, blood, feces and feathers can indicate intra-individual changes in the diet of migratory songbirds. Oecologia 142:501-510

Post DM (2002) Using stable isotopes to estimate trophic position: models, methods, and assumptions. Ecology 83: 703-718 
R Development Core Team (2008) R: a language and environment for statistical computing. R Foundation for Statistical Computing, Vienna. www.R-project.org

Riera P, Richard P, Grémare A, Blanchard G (1996) Food source of intertidal nematodes in the Bay of MarennesOléron (France), as determined by dual stable isotope analysis. Mar Ecol Prog Ser 142:303-309

Rossi F, Herman PMJ, Middelburg JJ (2004) Interspecific and intraspecific variation of $\delta^{13} \mathrm{C}$ and $\delta^{15} \mathrm{~N}$ in deposit- and suspension-feeding bivalves (Macoma balthica and Cerastoderma edule): evidence of ontogenetic changes in feeding mode of Macoma balthica. Limnol Oceanogr 49:408-414

Round FE, Crawford RM, Mann DG (1990) The diatoms. Cambridge University Press, Cambridge

Rubenstein DR, Hobson KA (2004) From birds to butterflies: animal movement patterns and stable isotopes. Trends Ecol Evol 19:256-263

Smith DJ, Underwood GJC (2000) The production of extracellular carbohydrates by estuarine benthic diatoms: the effects of growth phase and light and dark treatment. J Phycol 36:321-333

Stein RW, Place AR, Lacourse T, Guglielmo CG, Williams TD (2005) Digestive organ sizes and enzyme activities of refuelling western sandpiper (Calidris mauri): contrasting effects of season and age. Physiol Biochem Zool 78: $434-446$

Sutherland TF, Grant J, Amos CL (1998a) The effect of carbohydrate production by the diatom Nitzschia curvilineata on the erodibility of sediment. Limnol Oceanogr 43:65-72

Sutherland TF, Amos CL, Grant J (1998b) The effect of bouyant biofilms on the erodability of sublittoral sediments of a temperate microtidal estuary. Limnol Oceanogr 43:225-235

Sutherland TF, Shepherd PCF, Elner RW (2000) Predation on meiofaunal and macrofaunal invertebrates by western sandpiper (Calidris mauri): evidence for dual foraging modes. Mar Biol 137:983-993

Editorial responsibility: Peter Steinberg, Sydney, New South Wales, Australia
Tomas CR (ed) (1997) Identifying marine phytoplankton. Academic Press, San Diego, CA

> Tsipoura N, Burger J (1999) Shorebird diet during spring migration stopover on Delaware Bay. Condor 101:635-644

> Van der Wal D, Herman PMJ, Forster RM, Ysebaert T, Rossi F, Knaeps E, Plancke YMG, Ides SJ (2008) Distribution and dynamics of intertidal macrobenthos predicted from remote sensing: response to microphytobenthos and environment. Mar Ecol Prog Ser 367:57-72

Volcani BE (1981) Cell wall formation in diatoms. In: Simpson $\mathrm{T}$ L, Volcani BE (eds) Silicon and siliceous structures in biological systems. Springer, New York, NY, p 157-200

Warnock N, Bishop MA (1998) Spring stopover ecology of migrant western sandpiper. Condor 100:456-467

Wilson HW (1994) The western sandpiper (Calidris mauri). In: Poole A, Gill F (eds) The birds of North America 90. American Ornithologists' Union, Washington, DC, xcp 1-18

> Winemiller KO, Akin S, Zeug SC (2007) Production sources and food web structure of a temperate tidal estuary: integration of dietary and stable isotope data. Mar Ecol Prog Ser 343:63-76

Witteveen BH, Worthy GAJ, Roth JD (2009) Tracing migratory movements of breeding North Pacific humpback whales using stable isotope analysis. Mar Ecol Prog Ser 393:173-183

> Yokoyama H, Tamaki A, Harada K, Koyama K, Ishihi Y, Shimoda K, Harada K (2005) Isotopic evidence for phytoplankton as a major food source for macrobenthos on an intertidal sandflat in Ariake Sound, Japan. Mar Ecol Prog Ser 304:101-116

Yokoyama H, Ishihi Y, Yamamoto S (2008) Diet-tissue isotopic fractionation of the Pacific oyster Crassostrea gigas. Mar Ecol Prog Ser 358:173-179

Zwarts L, Wanink JH (1993) How the food supply harvestable by waders in the Wadden Sea depends on the variation in energy density, body weight, biomass, burying depth and behaviour of tidal-flat invertebrates. Neth J Sea Res 31: $441-476$

Submitted: May 10, 2010; Accepted: January 23, 2011 Proofs received from author(s): April 14, 2011 